\title{
EFFECT OF THIAMIN OR NIACIN SUPPLEMENTATION INTO THE RATIONS OF GROWTH FATTENING CALVES ON THEIR PRODUCTIVE PERFORMANCE
}

\author{
M.R.M. Mostafa; Ebtehag, I.M. Abou Elenin; A.A. Abdou; and W. Abdelaziz Riad. \\ Animal Production Research Institute, ARC, Giza, Egypt.
}

(Received 20/10/2015, Accepted 30/11/2015)

\section{SUMMARY}

\begin{abstract}
$\mathrm{T}$
his study aimed to evaluate the effect of feeding supplemented diets by two levels of thiamin or niacin on the productive performance of growing - fattening calves. A feeding trial was conducted using twenty five yearling Friesian calves of an initial weight ranged from $200-250 \mathrm{~kg} / \mathrm{head}$. Animals were divided into five similar groups (5 each) using the randomized complete block design. They were fed individually about $180-\mathrm{d}$ of an experimental period on a basal concentrate - roughage ration that consisted of approximately $56 \%$ concentrate feed mixture (CFM), $28 \%$ rice straw (RS) and $16 \%$ corn silage (CS), on DM basis, wherein $\mathrm{T}_{1}$ (control) had no supplement, $\mathrm{T}_{2}$ and $\mathrm{T}_{3}$ had 200 or $500 \mathrm{mg}$ thiamin/h/d and $\mathrm{T}_{4}$ and $T_{5}$ had 500 and $1000 \mathrm{mg}$ niacin/h/d, respectively. Animals were fed according to NRC,(1984) standard for beef cattle. At the same time, five digestibility trial were conducted to determine the digestibility and feeding value of the experimental rations. Results indicated that digestion coefficients of DM and OM were insignificantly increased with all supplemented rations except that of high level - niacin ration $\left(\mathrm{T}_{5}\right)$ which significantly increased, compared with control. Most nutrients digestibility were markedly improved by both supplements, the highest value $(\mathrm{p}<0.05)$ was occurred with the high level of niacin supplement $\left(\mathrm{T}_{5}\right)$. Similar trend for the feeding values (TDN, DCP and DE) was found among dietary treatments. Showing the highest feeding value with $\left(\mathrm{T}_{5}\right)$ total live body gain and daily gain were significantly increased due to both supplements (thiamin \& niacin) and its levels, being 158.8, 187.6, 164.6, 167.6 and $188.8 \mathrm{~kg}$ total gain versus $882,1042,914,931$ and 1049/gm as daily gain for $\mathrm{T}_{1}, \mathrm{~T}_{2}, \mathrm{~T}_{3}, \mathrm{~T}_{4}$ and $\mathrm{T}_{5}$, respectively. Feed conversion as DM: gain was slightly improved for calves fed rations whose supplemented by low level thiamin and both levels of niacin. Blood total protein and albumin concentrations were significant higher for all supplemental rations than those of unsupplemented one. Economically, the best net revenue was occurred with low thiamin and high niacin supplemented rations, being 12.10 and $12.70 \mathrm{LE} / \mathrm{head} /$ day, respectively. The corresponding economical efficiency values were 112 and $114 \%$ based on control ration (100\%). It cloud be concluded that using either thiamin or niacin as feed additive in ration formulation of growing and fattening Friesian calves tended to improve productive performance and economical efficiency for fattening calves, with the best results are associated with niacin supplement.
\end{abstract}

Keywords: Thiamin, niacin, feeding ruminants, supplementation and fattening calves.

\section{INTRODUCTION}

Today nutritionist have working for increasing the vital role of the huge kinds and number of feed additives to reduce the feed input with maximizing the feed conversion efficiency and in turn raising the productive efficiency as well. A massive effort are still on the race to incorporate such additives in order to guarantee the full benefit of the animals' rations and consequently increasing the production of farm animals. There are an endless of varieties of feed additives and accurately must be choose the most suitable and effective one. It is generally accepted that the mature ruminant animals does not require B vitamin supplementation because its ruminal microbs are able to synthesizing enough amount of these compounds to avoid deficiency symptoms (McDowell, 2000). However, changes in the roughage to concentrate ratio of the diet are known to alter the microbial activities in the rumen (Girardet al., 1994). Also, Santschi et al.(2005) revealed that ruminal B - vitamin concentration can be altered by dietary manipulation, changes in forage to concentrate ratio, composition of the diet and the dynamic environment of the rumen due to the continuous flow of the digesta. Earlier research findings suggested that microbial production of niacin in the rumen does not meet requirements of growing calves (Girard, 
1998) and oral administration of niacin has resulted to increase microbial protein synthesis (Shieldset al., 1983 and Flachowsky, 1993) and VFA (Doreau and Ottou, 1996 and Ottou and Doreau, 1996). In addition, Kumar and Dass (2005) concluded that supplementation of niacin into the diet of buffaloes had improved the rumen fermentation by decreasing the concentration of ammonia $-\mathrm{N}$ and increasing protein synthesis. Further results (Flachowsky, 1993) indicated that beef cattle appeared to be beneficial as niacin supplementation at $1 \mathrm{gm} / \mathrm{h} / \mathrm{d}$ or about $100 \mathrm{mg} / \mathrm{kg} \mathrm{DM}$ when body weight of bulls is lower than $300 \mathrm{~kg}$ and the diet are poor in protein (10 to $12 \%) \mathrm{CP}$ of DM and during dietary adaptation period. The ruminal thiamin concentration is a result of thiamin synthesis and degradation by ruminant microorganisms (Harmeyer and Kallenkirchen, 1989). The activity of rumen microorganisms is determined by the rumen conditions. This means that rumen conditions are the main determinant of the thiamin supply in ruminants. Both rumen conditions and the activity of rumen microorganisms are strongly affected by feeding conditions particularly intake level, concentrate level, roughage quality, nutrients balance etc. A sudden drop in ruminal $\mathrm{pH}$ can induce increased thiaminase activity which can destroy the thiamin and results to thiamin deficiency (Zinnet al., 1987). In Egypt, Kholif et al.(2009) found that addition $340 \mathrm{mg}$ thiamin /cow /day to the cows' rations increased milk yield by $13 \%$ and milk protein yield by $16 \%$ based on control ration that free from thiamin. Also, Solouma et al.(2013) recorded similar results in which 40 $\mathrm{mg} / \mathrm{h} / \mathrm{d}$ thiamin supplemented into the diet of ewes. It was improved blood metabolites and in turn significantly increased milk yield and milk composition as well as reduced the somatic cell count in ewe milk. Moreover, positive significant effect on growth performance was reported by El-Shanti et al.(2012) due to the addition of 20 or $40 \mathrm{mg} / \mathrm{h} / \mathrm{d}$ thiamin in rations of Assaf lambs. So far, the literature presents an inconclusive reports with somewhat conflicting results about the effects of ration formulation and composition on ruminal B-vitamins fractions concentrations. The present study was conducted to evaluate the supplementation of two levels of either thiamin or niacin on growth - fattening performance of Friesian calves.

\section{MATERIAL AND METHODS}

This work was carried out at Sakha Animal Production Research Station, Kafr El-Sheikh Province, that belongs to Animal Production Research Institute, Agriculture Research center (ARC), Ministry of Agriculture. A feeding trial was conducted using twenty five yearling Friesian calves of an initial weight ranged from 200 to $250 \mathrm{~kg} / \mathrm{head}$, to study the effect of supplementing two levels of either thiamin or niacin into their rations on growth-fattening performance. Animals were divided into five similar groups (5 each) using the randomized complete block design and they were fed individually for about 180-d as experimental period. A basal ration, consisted of 56\% CFM, 28\% RS and 16\% CS . It was calculated on DM basis, where the $\left(T_{1}\right)$ as a control ration without additive, while $T_{2}$ and $T_{3}$ had 200 and $500 \mathrm{mg} / \mathrm{h} / \mathrm{d}$ thiamin, $\mathrm{T}_{4}$ and $\mathrm{T}_{5}$ had 500 and $1000 \mathrm{mg} / \mathrm{h} / \mathrm{d}$ niacin, respectively. Animals were fed according to NRC, (1984) standard for beef cattle. Fresh water was free along the day round. All animals were vaccinated and treated in accordance of the established routine of the feedlot and they injected with vitamins $\mathrm{AD}_{3} \mathrm{E}$ to cover their requirements. Shrunk weights of animals after overnight withdrawal of feed and water were recorded for two consecutive days at the beginning and the end of the trial and every two weeks in between as well. Five in vivo digestibility trials were conducted simultaneously on the animals of the feeding trial, to determine the digestibility and feeding values of the experimental rations. Acid Insoluble Ash (AIA) method was used as described by Van Keulen and Young (1977). Fecal grab samples of nearly $200 \mathrm{gm}$ were taken from the rectum twice daily at 8 am and $6 \mathrm{pm}$ for $7-\mathrm{d}$ collection period that preceded by $10-\mathrm{d}$ transition period. Representative samples of feed and faces were taken for proximate analysis according to (AOAC, 1995). Jugular vein blood samples were taken in centrifuging tubes containing anticoagulant (EDTA) from three calves of each group before morning feeding. The sampling time was at the middle day of the experimental period. The plasma total protein (TP) and albumin were determined according to Peters (1968) and Doumas (1971), respectively. Globulin was estimated by difference. Activities of transminases (AST and ALT) were estimated according to Reitman and Frankel (1957) and Creatinine was measured according to Bartels (1971). Rumen liquor samples were collected using stomach tube during the collection period of digestibility trials from three animals of each group at 3 hours post feeding. Ruminal $\mathrm{pH}$ was determined immediately after straining the samples using digital $\mathrm{pH}$ meter-201. Concentrations of total VFAs and ammonia-N were determined according to the methods of Warner (1964) and Conway and O'Mally (1957), respectively. Economical efficiency was expressed as the ratio between the cost of output (weight gain) and the input (feed consumed) and also as feed cost:gain, based on the current price (LE/ton), which CFM, CS and RS were ranged 2800, 400 and 300, respectively. Thiamin was priced $180 \mathrm{LE} / \mathrm{kg}$ and niacin $80 \mathrm{LE}$. The price of live body weight was 35 
LE/kg. Data were statistically analyzed using general linear model program of SAS (1999). Using the following model:

$$
\mathrm{Y}=\mu+\mathrm{x}_{\mathrm{i}}+\mathrm{e}_{\mathrm{ij}}
$$

Where: $Y=$ observation. $\mu=$ mean, $\mathrm{Xi}=$ the effect of treatment, $\mathrm{e}_{\mathrm{ij}}=$ experimental error.

Duncan's multiple range test was employed to test for significant differences (Duncan, 1955).

\section{RESULTS AND DISCUSSION}

\section{Chemical composition:}

The chemical composition, the experimental basal ration and its ingredients are presented in Table 1. The proximate analyses of either corn silage or rice straw obtained in this study were commonly comparable to those recorded in the literature. The content of CP (14.4\%) and NFE (62.87\%) of CFM were also within the normal range of the different manufactured concentrates that usually used for fattening calves. The proximate as well as the crude fiber fractions (NDF, ADF, ADF, cellulose and hemicellulose) of corn silage and rice straw those obtained in this study were commonly comparable to those have been recorded in the literature.

Table (1): Chemical composition and Cell wall constituents (\%) of feed ingredients and calculated chemical composition of basal ration (\% on DM basis).

\begin{tabular}{lllll}
\hline Item & Concentrate & Corn Silage & $\begin{array}{l}\text { Rice } \\
\text { Straw }\end{array}$ & $\begin{array}{l}\text { Basal } \\
\text { Ration }\end{array}$ \\
\hline DM & 92.60 & 24.90 & 93.17 & 81.93 \\
OM & 90.89 & 92.46 & 85.24 & 89.56 \\
CP & 14.40 & 9.80 & 4.80 & 10.98 \\
CF & 12.80 & 27.32 & 33.2 & 20.84 \\
EE & 1.62 & 2.15 & 1.32 & 1.62 \\
Ash & 9.11 & 7.54 & 14.76 & 10.44 \\
NFE & 62.07 & 53.19 & 45.92 & 56.13 \\
Cell wall constituents $(\%):$ & & & & \\
NDF & 33.29 & 61.20 & 72.00 & 48.59 \\
ADF & 18.15 & 37.17 & 50.00 & 30.11 \\
ADL & 7.50 & 7.37 & 21.00 & 11.26 \\
Hemicellulose & 15.14 & 24.03 & 22.00 & 18.48 \\
Cellulose & 10.65 & 29.8 & 29.00 & 18.85 \\
\hline
\end{tabular}

\section{Digestibility and feeding values:}

Data of digestion coefficients and feeding values of the experimental rations are presented in Table 2. Based on control ration, digestibility of DM and $\mathrm{OM}$ insignificantly increased with rations $\mathrm{T}_{2}, \mathrm{~T}_{3}$ and $\mathrm{T}_{4}$ while it was increased significantly with $\mathrm{T}_{5}$ (high level of niacin). Also, CF digestibility was improved due to the addition of the two levels of either thiamin or niacin, in which the improvement was insignificant with thiamin $\left(\mathrm{T}_{2} \& \mathrm{~T}_{3}\right)$ and significant with niacin supplement $\left(\mathrm{T}_{4} \& \mathrm{~T}_{5}\right)$, compared with control ration $\left(\mathrm{T}_{1}\right)$ by comparable responses to that of $\mathrm{CF}$ digestibility were observed due to the dietary treatments respecting the digestibility value of fiber fractions (NDF, ADF, ADF, cellulose and hemicellulose). Similar trend was observed with EE digestibility values among treatments. Regarding the digestibility of NFE, supplementation of thiamin by the two levels (T2\&T3) had no significant effects on its values compared with control one, while only the high level of niacin supplement $\left(\mathrm{T}_{4} \& \mathrm{~T}_{5}\right)$ had significant positive effect on NFE digestibility based on control. Many researchers (Schussler et al., 1978, Kung et al., 1980 and Erickson et al., 1990) concluded that the variability of the response to the exogenous niacin may depend on dietary factors, including the content of dietary protein and the percentage of concentrates in the diet. Specifically, Doreau and Ottou (1996) revealed that supplementing niacin did not modify ruminal or apparent total tract digestibility in cows to any great extent. They added that the enhancement of DM degradation in-situ did not result to quantitative modification of ruminal digestion. However, the positive effect of niacin on protozoal number has been confirmed. The present results are in harmony with those obtained by Hironaka and Kozub (1991) who found that DM and CP 
digestibility were higher for thiamin-supplemented diet than those non-supplemented one, showing no affected on digestibility.

Table (2): Nutrients and Cell wall constituents digestibility and feeding values of fed fattening calves.

\begin{tabular}{lllllll}
\hline & \multicolumn{5}{c}{ Dietary treatments } \\
\cline { 2 - 5 } Item & T1 & T2 & T3 & T4 & T5 & \pm SE \\
\hline Nutrients Digestibility, (\%): & & & & & & \\
DM & $52.26^{\mathrm{b}}$ & $55.00^{\mathrm{b}}$ & $52.58^{\mathrm{b}}$ & $58.08^{\mathrm{ab}}$ & $63.05^{\mathrm{a}}$ & 3.047 \\
OM & $55.49^{\mathrm{b}}$ & $58.48^{\mathrm{b}}$ & $56.37^{\mathrm{b}}$ & $61.51^{\mathrm{ab}}$ & $67.26^{\mathrm{a}}$ & 3.354 \\
CP & $56.07^{\mathrm{b}}$ & $60.50^{\mathrm{a}}$ & $58.24^{\mathrm{ab}}$ & $59.01^{\mathrm{ab}}$ & $65.44^{\mathrm{a}}$ & 3.231 \\
CF & $39.84^{\mathrm{c}}$ & $47.44^{\mathrm{abc}}$ & $43.97^{\mathrm{bc}}$ & $51.80^{\mathrm{ab}}$ & $55.72^{\mathrm{a}}$ & 3.424 \\
EE & $61.02^{\mathrm{c}}$ & $67.89^{\mathrm{bc}}$ & $60.41^{\mathrm{b}}$ & $72.76^{\mathrm{ab}}$ & $76.67^{\mathrm{a}}$ & 2.885 \\
NFE & $61.02^{\mathrm{b}}$ & $61.92^{\mathrm{b}}$ & $60.49^{\mathrm{b}}$ & $65.28^{\mathrm{ab}}$ & $71.62^{\mathrm{a}}$ & 3.466 \\
Cell wall constituents (\%): & & & & & \\
NDF & $35.17^{\mathrm{c}}$ & $44.40^{\mathrm{ab}}$ & $37.13^{\mathrm{bc}}$ & $46.01^{\mathrm{a}}$ & $50.24^{\mathrm{a}}$ & 2.378 \\
ADF & $29.35^{\mathrm{c}}$ & $36.21^{\mathrm{abc}}$ & $32.00^{\mathrm{bc}}$ & $38.15^{\mathrm{ab}}$ & $41.04^{\mathrm{a}}$ & 2.147 \\
ADL & $13.89^{\mathrm{b}}$ & $19.26^{\mathrm{ab}}$ & $17.05^{\mathrm{b}}$ & $23.52^{\mathrm{ab}}$ & $27.16^{\mathrm{a}}$ & 2.858 \\
Hemicellulose & $44.65^{\mathrm{b}}$ & $57.75^{\mathrm{a}}$ & $45.48^{\mathrm{b}}$ & $58.82^{\mathrm{a}}$ & $65.23^{\mathrm{a}}$ & 3.506 \\
Cellulose & $38.58^{\mathrm{b}}$ & $46.34^{\mathrm{ab}}$ & $40.94^{\mathrm{ab}}$ & $46.88^{\mathrm{ab}}$ & $49.33^{\mathrm{a}}$ & 2.494 \\
Feeding values (\%): & & & & & \\
TDN\% & $50.93^{\mathrm{b}}$ & $53.75^{\mathrm{b}}$ & $51.71^{\mathrm{b}}$ & $56.56^{\mathrm{ab}}$ & $61.79^{\mathrm{a}}$ & 2.969 \\
DCP\% & $6.15^{\mathrm{b}}$ & $6.64^{\mathrm{a}}$ & $6.39^{\mathrm{ab}}$ & $6.48^{\mathrm{ab}}$ & $7.18^{\mathrm{a}}$ & 1.231 \\
DE (Mcal/Kg DMI) ${ }^{\mathrm{a}}$ & $2.25^{\mathrm{b}}$ & $2.37^{\mathrm{b}}$ & $2.28^{\mathrm{b}}$ & $2.49^{\mathrm{ab}}$ & $2.72^{\mathrm{a}}$ & 0.130 \\
\hline
\end{tabular}

A: $D E($ Mcal/ Kg DMI) $=0.04409 \times T D N \%$ (NRC, 1988); SE= standard error

$a, b$ and $c$ : Means in the same rows with differ rent superscripts are significantly different at $(P<0.05)$.

$T_{1}=$ control $; T_{2}=0.2 \mathrm{~g}$ Thiamin $; T_{3}=0.5 \mathrm{~g}$ Thiamin $; T_{4}=0.5 \mathrm{~g}$ Niacin and $T 5=1 \mathrm{~g}$ Niacin .

In perspective, the modulatory effect of supplementation niacin or thiamin into the diets of ruminants greatly dependent on dietary factors and consequently the rumen condition that currently seems to be in very dynamic state. Results of Kumar and Dass (2005) demonstrated that niacin supplementation in diet of buffaloes had improved the rumen fermentation by decreasing ammonia-N concentration and increasing protein synthesis. While, Shaver and Bal (2000) found that in-situ DM degradation of alfalfa silage was unaffected by dietary thiamin supplementation (68.8\% and 69.0\%) for un - or supplemented diets, respectively. Results of these trials suggested a possible role for thiamin supplementation when dietary contents of NDF and ADF are lower and non-fiber carbohydrate is higher than recommended. In matching with DM and OM digestibility values, the feeding values that expressed as TDN, DCP and DE of tested rations were improved compared with control one, with the highest $(p<0.05)$ values which were occurred with higher level of niacin supplement $\left(\mathrm{T}_{5}\right)$. These results are in harmony with the findings obtained by Gabr et al., (2004) who found a markedly improvement in TDN and DCP values when supplemented sheep diets with yeast culture.

\section{Animals performance:}

Data of daily feed intake, total live body gain, daily gain and feed conversion ratio of calves fed the dietary experimental treatments are presented in Table (3).

\section{Daily feed intake:}

The daily feed intake that expressed as DM, TDN, DCP and DE were markedly increased with supplemented tested rations compared with the unsupplemented one. Statistically DM intake was significantly higher with most of tested rations than that of control one, the highest values were occurred with supplemented rations (T2, T3 and T5). The increases in feed intake in supplemented rations could be attributed to the marked improvement in DCP values of these rations as shown in Table 2. In connection with this point, Miller (2002) revealed that sufficient nitrogen and rumen degradable protein must be supplied to maximize bacterial fermentation, energy digestibility and feed intake. Consecutively, digestion of fibrous feeds, which in turn increasing DM intake, is also increased by the provision of performed dietary protein (Carro and Miller, 1999). Results here are in agreement with the findings obtained by Mehrez et al. (2013) who found that daily feed intake increased as the level of yeast (rich in vit. B) increased up $5 \mathrm{gm} / \mathrm{animal}$ (lamb). Conclusively, Nocek and Russell (1988) suggested that the stimulating effect involves a cycle of improved efficiency of microbial protein synthesis, increased DM 
digestibility and thereby increased feed intake. Erasmus et al.(1992) and Wang et al.(2001) reported that an increase of DMI with yeast culture supplementation, but Kamalamma et al.(1996) and El - Shanti et al.(2012) did not observed an effect of yeast culture or thiamin on DMI, respectively.

\section{Body weight gain:}

Results presented in Table 3 showed that final body weight, total body weight gain and daily gain were significant increase in tested rations due to the source (thiamin \& niacin) of supplements and its levels, compared with unsupplemented one (control), being the highest values were associated with low thiamin $\mathrm{T}_{2}$ (200mg thiamin) and the high level niacin $\mathrm{T}_{5}(1000 \mathrm{mg}$ niacin). Clearly it could be attributed to the intake of TDN and DCP are markedly higher with $\mathrm{T}_{2}$ and $\mathrm{T}_{5}$ than the other treatments as shown in Table 3. Many research findings suggested that microbial production of niacin in the rumen does not meet the requirements of growing calves (Girard, 1998) and oral administration of niacin has resulted in an increased microbial protein synthesis (Shields et al., 1983 and Flachowsky, 1993) and VFA (Doreau and Ottou, 1996 and Kumar and Dass, 2005).

Table (3): Average feed intake, body weight gain and feed efficiency for fattening calves fed experimental rations.

\begin{tabular}{|c|c|c|c|c|c|c|}
\hline \multirow{2}{*}{ Item } & \multicolumn{5}{|c|}{ Dietary treatments } & \multirow{2}{*}{$\pm \mathrm{SE}$} \\
\hline & $\mathrm{T}_{1}$ & $\mathrm{~T}_{2}$ & $\mathrm{~T}_{3}$ & $\mathrm{~T}_{4}$ & $\mathrm{~T}_{5}$ & \\
\hline \multicolumn{7}{|l|}{ Feed intake (kg/head/day) as fed: } \\
\hline CFM & 6.90 & 7.27 & 7.27 & 6.43 & 7.14 & \\
\hline $\mathrm{CS}$ & 6.90 & 7.27 & 7.27 & 6.43 & 7.14 & \\
\hline RS & 3.45 & 3.63 & 3.63 & 3.22 & 3.57 & \\
\hline Feed additives $(\mathrm{gm})$ & --- & 0.2 & 0.5 & 0.5 & 1.0 & \\
\hline \multicolumn{7}{|c|}{ Feed intake ( $\mathrm{kg} / \mathrm{head} /$ day) on DM basis: } \\
\hline CFM & 6.39 & 6.73 & 6.73 & 5.96 & 6.62 & \\
\hline $\mathrm{CS}$ & 1.72 & 1.81 & 1.81 & 1.60 & 1.78 & \\
\hline RS & 3.21 & 3.39 & 3.39 & 3.00 & 3.33 & \\
\hline \multicolumn{7}{|l|}{ Total intake (kg) as: } \\
\hline DM intake (kg/day) & $11.32^{\mathrm{c}}$ & $11.92^{\mathrm{a}}$ & $11.92^{\mathrm{a}}$ & $10.56^{\mathrm{b}}$ & $11.72^{\mathrm{a}}$ & 0.126 \\
\hline TDN intake (kg/day) & 5.77 & 6.41 & 6.16 & 5.97 & 7.24 & \\
\hline DCP intake (kg/day) & 0.70 & 0.79 & 0.76 & 0.68 & 0.84 & \\
\hline DE (Mcal/kg DMI) & 0.25 & 0.28 & 0.27 & 0.26 & 0.32 & \\
\hline Roughage/concentrate & $56: 44$ & $56: 44$ & $56: 44$ & $56: 44$ & $56: 44$ & \\
\hline \multicolumn{7}{|l|}{ Live body weight, kg: } \\
\hline Initial body weight & 203.6 & 209.4 & 205.6 & 209.0 & 208.0 & N.S. \\
\hline Final body weight & $362.4^{\mathrm{c}}$ & $397.0^{\mathrm{a}}$ & $370.2^{\mathrm{b}}$ & $376.6^{\mathrm{b}}$ & $396.8^{\mathrm{a}}$ & 3.561 \\
\hline Total live body weight gain $(\mathrm{kg})$ & $158.8^{\mathrm{c}}$ & $187.6^{\mathrm{a}}$ & $164.6^{\mathrm{b}}$ & $167.6^{\mathrm{b}}$ & $188.8^{\mathrm{a}}$ & 2.972 \\
\hline Av. Daily Gain (gm) & $882^{\mathrm{c}}$ & $1042^{\mathrm{a}}$ & $914^{\mathrm{b}}$ & $931^{\mathrm{b}}$ & $1049^{\mathrm{a}}$ & 2.113 \\
\hline \multicolumn{7}{|l|}{ Feed Conversion : } \\
\hline kg DM feed intake / kg gain & $12.83^{\mathrm{ab}}$ & $11.44^{\mathrm{b}}$ & $13.04^{\mathrm{a}}$ & $11.34^{\mathrm{ab}}$ & $11.17^{\mathrm{b}}$ & 0.143 \\
\hline $\mathrm{kg}$ TDN feed intake /kg gain & 6.54 & 6.15 & 6.74 & 6.42 & 6.90 & \\
\hline $\mathrm{kg}$ DCP feed intake $/ \mathrm{kg}$ gain & 0.79 & 0.76 & 0.83 & 0.73 & 0.80 & \\
\hline
\end{tabular}

$a, b$ and $c:$ Mean in the some row with different supersipts are significantly $(p<0.05)$ different

In other study, Shaver and Bal (2000) concluded that marginal B. vitamin deficiency, however, occur in mature ruminants when requirements of B - vitamins are high or when decreased microbial synthesis or increased distraction of B - vitamins in the rumen. Such condition has been found in the high performance cows, fattening cattle and sheep. Growth - fattening performance results in the present study are in agreement with the findings reported by Flachowsky (1993) who indicated that beef cattle appeared to be beneficial as niacin supplementation at $1 \mathrm{gm} / \mathrm{h} / \mathrm{d}$ or about $100 \mathrm{mg} / \mathrm{kg}$ DM when body weight of bulls is lower than $300 \mathrm{~kg}$ and diets are poor in protein content (10 to 12\%) of DM and during dietary adaptation period. On other experiment, influence of added niacin $(0.0,0.5$ or $1.0 \mathrm{gm} / \mathrm{h} / \mathrm{d})$ and $\mathrm{CP}$ content (9.0 to $12.0 \%$ ) of DM or supply of various N-source (urea, rapeseed meal, soybean meal or fish meal) were investigated respecting rumen fermentation, feed intake and weight gain with growing bulls weighing 175 to $300 \mathrm{~kg}$. Niacin increased weight gain with urea $(43 \mathrm{gm} / \mathrm{h} / \mathrm{d})$ and increasing rapeseed or soya- rations $(60 \mathrm{gm} / \mathrm{h} / \mathrm{d})$, but did not influence in fish meal-ration. Increasing weight gain resulted from ruminal and metabolic effects (about 2/3) as well as enhanced feed intake of bulls (1/3), (Flachowsky, 1993). In case of thiamin, El-Shanti et al. (2012) found similar effect in which 20 or $40 \mathrm{mg} / \mathrm{h} / \mathrm{d}$ were 
incorporated in diets of lambs, being both levels enhanced growth performance, however, the highest values were found with the low level. Also, Kholif et al. (2013) found similar results with ewes where 40 $\mathrm{mg} / \mathrm{h} / \mathrm{d}$ thiamin supplementation led to an increase in their milk yield. Earlier study proved that when diet of feedlot steer was supplemented by $0.190 \mathrm{mg}$ thiamin $/ \mathrm{kg}$ diet, the daily gain was significantly higher, being $1.4 \mathrm{~kg} / \mathrm{d}$ compared with $0.92 \mathrm{~kg} / \mathrm{d}$ in control (Grigat and Methison, 1982). In conclusion results reviewed in literature suggested a possible role of thiamin and niacin supplementations when dietary concentrations of NDF and ADF are lower and NFC is higher than recommended (Shaver and Bal, 2000).

Regarding feed conversion that expressed as DM, TDN or DCP: gain, it could be observed that nonsignificant effects due to the two supplements and its levels were found on feed conversion parameters (Table3). The lack of effect of dietary supplements (thiamin / niacin) on feed conversion might be somewhat due to the similarity of metabolic bioprocesses in the tissues of animals among experimental groups. Results regarding the effect of thiamin or niacin supplementation on feed conversion parameters on fattening calves is lacking in literature. Further studies are needed to verity to what extent thiamin / niacin supplementations to the high energy diet of beef cattle would be effect on fermentation pattern in rumen, metabolic processes and feed conversion.

\section{Rumen Liquor Parameters:}

Data related to rumen liquor measurements as $\mathrm{pH}$, ammonia-N and TVFA's concentrations are presented in Table 4. Significant increases in the values of $\mathrm{NH}_{3}-\mathrm{N}$ and TVFA's with four tested rations compared with the untreated one (control). Slightly variation among tested treatments respecting $\mathrm{NH}_{3}-\mathrm{N}$ and TVFA's concentrations could be observed. Also $\mathrm{pH}$ values seemed to be within in very narrow range being 6.22 to 6.38 , however tested rations $T_{2}$ and $T_{5}$ had significantly the highest values. The increase in fermentation process and synthesized microbial protein that resulted chiefly from protozoa as addition niacin (Doreau and Ottou, 1996) which has been associated with simultaneous increases in ruminal ammonia-N and propionic acid. Also, in vitro studies showed beneficial effect of niacin supplement on microbial protein synthesis and TVFA's concentration. Further, Kumar and Dass (2005) revealed that supplementation of niacin into diet of buffaloes had stimulating effect on rumen fermentation with enhanced synthesis of microbial protein and TVFA's. These results are similar to the findings of (Nangia et al., 2000 and Ghosh and Kewalramni, 2002) who also observed an increase in TVFA's concentration due to added niacin supplement in the diet of buffaloes. Earlier Brent and Bartley (1984) stated that thiamin activity was higher for animals fed high concentrate diets with low rumen $\mathrm{pH}$. The present results are in harmony with those findings of Mehrez et al.(2013) who found an increases respecting $\mathrm{NH}_{3}-\mathrm{N}_{\text {and }}$ TVFA's contents responding to the diets of lambs that supplemented by the two levels of live yeast that well known, considered as a viable source of vitamin B-complex.

Table (4): Some rumen liquor and blood parameters of fattening calves fed experimental rations.

\begin{tabular}{lcccccc}
\hline & \multicolumn{7}{c}{ Dietary treatments } & \multirow{2}{*}{ $\pm S E$} \\
\cline { 2 - 6 } Item & $\mathrm{T}_{1}$ & $\mathrm{~T}_{2}$ & $\mathrm{~T}_{3}$ & $\mathrm{~T}_{4}$ & $\mathrm{~T}_{5}$ & \\
\hline Rumen Parameters: & & & & & & \\
$\mathrm{pH}$ & $6.25^{\mathrm{b}}$ & $6.38^{\mathrm{a}}$ & $6.22^{\mathrm{b}}$ & $6.31^{\mathrm{ab}}$ & $6.35^{\mathrm{a}}$ & 0.231 \\
$\mathrm{NH}_{3}-\mathrm{N}(\mathrm{mg} / 100 \mathrm{ml})$ & $21.42^{\mathrm{c}}$ & $22.92^{\mathrm{a}}$ & $21.97^{\mathrm{b}}$ & $22.08^{\mathrm{b}}$ & $23.01^{\mathrm{a}}$ & 1.021 \\
TVFA's $^{\mathrm{a}}$ (m.eq./100ml) & $14.36^{\mathrm{c}}$ & $15.65^{\mathrm{a}}$ & $15.70^{\mathrm{a}}$ & $15.05^{\mathrm{b}}$ & $15.65^{\mathrm{a}}$ & 0.521 \\
T. protein (g/dl) & $6.79^{\mathrm{c}}$ & $7.53^{\mathrm{b}}$ & $7.50^{\mathrm{b}}$ & $7.51^{\mathrm{b}}$ & $7.64^{\mathrm{a}}$ & 0.413 \\
Albumin (g/dl) & $3.66^{\mathrm{b}}$ & $4.21^{\mathrm{a}}$ & $4.09^{\mathrm{a}}$ & $4.13^{\mathrm{a}}$ & $4.25^{\mathrm{a}}$ & 0.012 \\
Globulin (g/dl) & 3.13 & 3.23 & 3.41 & 3.38 & 3.39 & N.S. \\
Creatinine (mg/dl) & 1.38 & 1.39 & 1.33 & 1.34 & 1.37 & N.S. \\
AST (IU/L) & 36.78 & 36.65 & 36.89 & 36.75 & 36.63 & N.S. \\
ALT (IU/L) & 24.22 & 23.72 & 23.69 & 23.66 & 23.60 & N.S. \\
\hline
\end{tabular}

$a, b$ and $c:$ Means in the same rows with differ rent superscripts are significantly different at $(P<0.05)$.

\section{Blood Parameters:}

Data of some blood parameters are presented in Table 4. Concentrations of total protein and albumin were significantly higher for all supplemented rations by either thiamin or niacin and its levels than the unsupplemented one, being there were non-significant differences among the supplemented rations respecting these measurements. While globulin concentration did not significantly affected by dietary treatments. Also, no significant differences among the experimental treatments were noticed with respect 
of creatinine concentration and liver transminases activity (AST and ALT). These results may be supported by the previous mentioned results of rumen ammonia-N concentration that higher $(\mathrm{p}<0.05)$ in treated rations by thiamin and niacin than control as shown in Table 4. These results are in agreement with those reported by Meherz et al.(2013) who supplemented the diets of lambs by two levels of live yeast which was increased the concentrations of blood total protein and albumin significantly, while the concentrations of creatinine, GOT and GPT did not affected by the treatments. Also, similar results are recorded by Solouma et al. (2013) who experimented two levels of thiamin incorporated in the diets of Sohagi sheep. They were found increases in blood total protein and albumin percentages due to thiamin supplementation, with no significant effects on GOT and GPT activities. Otherwise, Kholif et al. (2009) found insignificant effect respecting the concentrations of most serum biochemical parameters due to supplementing the ration of lactating cows by thiamin. In contrary, El-Shanti et al. (2012) indicated that blood serum concentrations regarding total protein and albumin seemed to be decreased with thiamin inclusion in lambs' rations, but each of AST and ALT did not influenced significantly, being similar with those obtained by the present study. Furthermore, earlier Meherz et al.(2004) reported that total protein was significant higher with yeast culture supplementation to the diet of lambs than that of unsupplemented one, while albumin, globulin and liver enzymes (AST \& ALT) did not affected by this supplement. They concluded that yeast culture (as a good source of vit. B) supplementation to growing sheep diets had positive effects on their productive performance without any adverse effect on blood constituents and had higher influence when supplemented with high concentrate-diet than high roughage- diet.

\section{Economical efficiency:}

Economical evaluation data are presented in Table 5. In fact there are a huge kinds of feed additive especial those preparing by biochemistry - microbial processes probiotic and prebiotic compounds.

Table (5): Economical evaluation of fattening calves fed experimental rations.

\begin{tabular}{lccccc}
\hline & \multicolumn{5}{c}{ Dietary treatments } \\
\cline { 2 - 6 } Item & $\mathrm{T}_{1}$ & $\mathrm{~T}_{2}$ & $\mathrm{~T}_{3}$ & $\mathrm{~T}_{4}$ & $\mathrm{~T}_{5}$ \\
\hline Feed intake (kg/head/day) as fed: & & & & & \\
Concentrate feed mixture (CFM) & 6.90 & 7.27 & 7.27 & 6.43 & 7.14 \\
Corn Silage & 6.90 & 7.27 & 7.27 & 6.43 & 7.14 \\
Rice Straw & 3.45 & 3.63 & 3.63 & 3.22 & 3.57 \\
Average daily gain (kg) & 0.882 & 1.042 & 0.914 & 0.931 & 1.049 \\
Economic evaluation: & & & & & \\
Gain price (LE /day) & 30.88 & 36.48 & 32.01 & 32.59 & 36.71 \\
Feed Cost (LE/head/day): & & & & & \\
Concentrate Intake & 19.32 & 20.35 & 20.35 & 18.01 & 20.00 \\
Corn silage intake & 2.76 & 2.91 & 2.91 & 2.57 & 2.86 \\
Rice Straw intake & 1.04 & 1.09 & 1.09 & 0.97 & 1.07 \\
Price of additive (LE) & 0.00 & 0.04 & 0.09 & 0.04 & 0.08 \\
Total feed cost (LE/day) & 23.12 & 24.38 & 24.43 & 21.59 & 24.01 \\
Feed cost / kg gain & 26.20 & 23.39 & 26.72 & 23.19 & 22.89 \\
Net revenue(LE/head/day) & 7.76 & 12.10 & 7.57 & 11.00 & 12.70 \\
Increasing rates of net revenue (\%) & 100 & 156 & 98 & 142 & 164 \\
Economic efficiency & 1.34 & 1.50 & 1.31 & 1.51 & 1.53 \\
Improvement of economic efficiency (\%) & 100 & 112 & 98 & 113 & 114 \\
\hline
\end{tabular}

Diets of ruminants which including such additives increase the productive performance and in consequent increasing the economical efficiency. Results of the present study showed that feed cost per $\mathrm{kg}$ live weight gain was markedly decreased with supplemented rations, except that of high level all thiamin $\left(T_{3}\right)$. Also, the highest net revenue was occurred with low thiamin $\left(T_{2}\right)$ and high niacin $\left(T_{5}\right)$ supplemented rations being 12.10 and $12.70 \mathrm{LE} /$ head/day, respectively, while the lowest net revenue values were associated with the high level - thiamin $\left(T_{3}\right)$ ration and control one $\left(T_{1}\right)$ being 7.57 and 7.76 LE, respectively. Similar trend was observed among dietary treatments regarding economical efficiency value being $100,112,98,113$ and $114 \%$ for $\mathrm{T}_{1}, \mathrm{~T}_{2}, \mathrm{~T}_{3}, \mathrm{~T}_{4}$ and $\mathrm{T}_{5}$, respectively. Results here are matching with those obtained by Kholif et al. (2009) who worked with lactating cows and using thiamin supplement and El-Shanti et al.(2012) who used lambs with thiamin supplement and lastly Mehrez et 
al.(2013) who evaluated the effect of live yeast supplementation as a good source of vit. B- complex, on growing lambs performance.

\section{CONCLUSION}

This study could be emphasized on the vital role of vitamin-B supplementation into the diets of ruminants particularly in case of finishing phase of fattening calves. Results proved that each of thiamin or niacin supplements had an important role for improving the productive performance and tended to increase digestibility coefficients. Moreover, better feed and economical efficiency were found.

\section{REFERENCE}

AOAC (1995). Official Methods of analysis, $16^{\text {th }}$ Edt. Association of Official Analytical Chemists, Washington, DC, USA.

Bartels, H. (1971). A colormetric method for creatinine estimation. J. Clin. Chem. Acta., 32:81.

Brent, B.E. and E.E. Bartley (1984). Thiamine and niacin in the rumen. J. of Anim. Sci., 59:813-822.

Carro, M.D. and E.L. Miller (1999). Effect of supplementing a fiber basal diet with different nitrogen forms on ruminal fermentation and microbial growth in an in-vitro semi-continuous culture system (RUSITEC). British J. of Nutr., 82:149-157.

Conway, E.F. and E. O'Mally (1957). Micro diffusion methods. Ammonia and urea using buffered absorbents. Biochem. J., 36: 655.

Doreau. M. and J.F. Ottou (1996). Influence of niacin supplementation on in vivo digestibility and ruminal digestion in dairy cows. J. Dairy. Sci., 79:2247-2254.

Doumas, B. (1971). Colorimetric determination of albumin. Clin. Chem. Acta, 31: 87.

Duncan, D.B. (1955). Multiple range and Multiple F. test, Biometrics, 11:1.

El- Shanti, H.A.; A.M. Kholif; M.A. Hanafy; K.J. Al-Shakkrit and I.M. El- Hasaynah (2012). Effect of thiamin supplementation to diet on the productive performance of lambs. Egypt, J. Nutr. and Feeds, 15 (1): 67-80.

Erasmus, L.J.; P.M. Botha and A. Kistner (1992). Effect of yeast culture supplement on production, rumen fermentation and duodenal nitrogen flow in dairy cows. J. Dairy Sci., 75: 3056-3065.

Erickson, P.S.; A.M. Trusk and M.R. Murphy (1990). Effects of niacin source on epinephrine stimulation of plasma nonesterified fatty acid and glucose concentrations, on diet digestibility and on rumen protozoal numbers in lactating dairy cows. J. Nutr. 120:1648- 1653.

Flachowsky, G. (1993). Niacin in dairy and beef cattle nutrition. Arch. Anim. Nutr., 43: 195 -213.

Gabr, A.A.; A.Z. Mehrez; M.Y. El-Ayek; M.R.M. Mostafa and E. Kh. Hamed (2004). Influence of dry yeast cultur (Lacture) supplementation to sheep diets differing in roughage: concentration ratio on nutrient digestibilities, feeding values and some rumen parameters. $7^{\text {th }}$ vet. Med. Zag. Conf. (21-23 July), Sharm El - Sheikh.

Ghosh, N.R. and N. Kewalramani (2002). Comparative efficacy of niacin vs. nicotinamide on rumen fermentation and cellulolytic rumen enzymes in buffaloes. In: Proceedings of the IVth Biennial Conference and Exhibition of Anim. Nutr, Assoc., Kolkata, India.

Girard, C.L. (1998). B - complex vitamins for dairy cows - a new approach. Canad. J. Anim. Sci., 78 (Suppl): 71- 90.

Girard, C.L.; J. Chiquette and J.J. Matte (1994). Concentrations of folates in ruminal content of steers: response to dietary supplement of folic acid in relation with the nature of the diet. J. Anim. Sci., 72:1023-1028.

Grigat, G.A. and G.W. Mathison (1982). Thiamin supplementation of an all- concentrate diets for feedlot steers. Canad. J. Anim. Sci., 62:807-819.

Harmeyer, J. and U. Kollenkirchen (1989). Thiamin and niacin in ruminant nutrition. Nutr. Rev., 2:201225.

Hironaka, R. and G.C. Kozub (1991). Thiamin supplementation of beef cattle diets. Canad. J. Anim. Sci., $71: 1265$. 
Kamalamma, U. Kirshnamoorthy and P. Krishnappa (1996). Effect of feeding yeast culture (Yea-Sacc 1026) on rumen fermentation in vitro and production performance in crossbred dairy cow. Anim. Feed Sci. Techno., 57:247-256.

Kholif, A.M.; H.A. Hamdon and G.M.A. Solouma (2013). Effect of supplementing ration with thiamin on milk yield and composition in Sohagi sheep. $14^{\text {th }}$ Sci. Conf. Of Anim. Nutri., Nov., Hurgada

Kholif, A.M.; M.A. Hanafy; Ahlam, A. El - Shewy; M.H. Abdel Gawad and Eman S.A. Farahat (2009). Effect of supplementing rations with thiamin and /or sodium bicarbonate on milk yield and composition of lactating cows. Egypt, J. Nutr., Feeds, 12 (2): 187-195

Kumar, R.D. and R.S. Dass (2005). Effect of niacin supplementation on rumen metabolites in Murrah buffaloes (Bubalusbubalis). Asian-Austral J. Anim. Sci., 18(1): 38-41.

Kung, L.; K. Gubert and J.T. Huber (1980). Supplemental niacin for lactating cows fed diets of natural protein or non - protein nitrogen. J. Dairy Sci., 63:2020-2025.

McDowell, L.R. (2000). Vitamins in animal and human nutrition. $2^{\text {nd }}$ ed. Iowa state Univ. Press Ames, USA. PP. 265.

Mehrez, A.Z.; A.A. Gabr; M.Y. El-Ayek; M.R.M. Mustafa and E.Kh. Hamed (2004). Growth performance of growing lambs fed diets differing in concentrate: roughage ratio and supplemented with a probiotic. Egypt, J. Anim. Prod. Supp. Issue (41): 267-274. Feeds 16 (1): 17-25.

Mehrez, A.Z.; A.A. Gabr; A.A. Mahrous; O.A. Zelak and Amal M.A. Fayed (2013). Influence of live yeast feed additives on productive performance of growing Rahmany lambs. J. Anim. and Poul. Prod. Mansoura Univ., 4(5): 233-247.

Miller, E.L. (2002). Protein source for the animal feed industry. Proc., Expert consul. and workshop, Bangkok, 29 April. - 3 May, FAO, Anim. and Health, pp.29.

Nangia, O.P.; M. Gupta; S. Sindhu and S.K. Garg (2000). Influence of niacin supplementation on rumen fermentation and microbial protein synthesis in buffaloes. Indian J. Anim. Sci., 70:764-765.

Nocek, J.E. and J.B. Russell (1988). Protein and energy as an integrated system. Relationship of ruminal protein and carbohydrate availability to microbial synthesis and milk production. J. Dairy Sci., 71:2070-2107.

NRC (1984). Nutrition Requirements of Beef Cattle $6^{\text {th }}$ Revised Ed., National Academy Press, Washington D.C.

NRC (1988). Nutrient Requirements of Dairy Cattle.6th Rev. Ed., National Research Council Acad.Sci., Washington, DC, USA

Ottou, J.F. and M. Doreau (1996). Influence of niacin on in vitro ruminal fermentation and microbial synthesis depending upon dietary factors. Anim. Feed Sci., Technol., 58:187-199.

Peters, T. (1968). Determination of blood total protein. Clin., Chem., 14: 1147.

Reitman, S. and S. Frankel (1957). Colorimetric methods for the determination of serum glutamic oxaloacetic and glutamic - Pyruvate transminases. Am. J. Clin., Pathol., 28:56.

SAS, (1999). SAS Procedure Guide. Version 6.12 Edition. SAS Institute Inc.,Cary,NC, USA.

Santschi, D.E.; J. Chiquette; R. Berthiaume; R. Martineau; R. Matte; A.F. Mustafa and C.L. Girard (2005). Effect of the forage to concentrate ratio on - vitamins concentrations in different ruminal functions of dairy cows. Can J Anim. Sci 85(3):389-399.

Schussler, S.L.; G.C. Fahey; J.B. Robinson; S.S. Masters; S.C. Lorech and J.W. Spears (1978). The effects of supplemental niacin on in-vitro cellulose digestion and protein synthesis. Int. J. Nutr. Res., 48:359.

Shaver, R.D. and M.A. Bal (2000). Effect of dietary thiamine supplementation on milk production by dairy cows. J. Dairy Sci., 83 (10): 2335-2340.

Shields, D.R.; D.M. Schaefer and T.W. Ferry (1983). Influence of niacin supplementation and nitrogen sources on rumen microbial fermentation. J. Anim. Sci., 57:1576-1583.

Solouma, G.M.A.; H.A. Hamdon and A.M. Kholif (2013). Effect of thiamin supplementation in ration on milk yield, composition and some blood components of Sohagi sheep. Egypt, J. Nutr. Feeds, 16 (1): 17-25.

Van Keulen, J. and B.A. Young (1977). Evaluation of acid -insoluble Ash as a natural marker in ruminant digestibility studies. J. Anim. Sci., 44: 282-287.

Wang, Z.; M.L. Eastride and X. Qui (2001). Effects of forage neutral detergent fiber and yeast culture on performance of cows during early lactation. J. Dairy Sci., 84: 204-212. 
Warner, A.C.I. (1964). Production of volatile fatty acids in the rumen. Methods of measurements. Nutr., Rev., 34: 339.

Zinn, R.A.; F.N. Owen; R.L. Stuart; J.R. Dundar; B.B. Norman (1987). B-vitamin supplementation of diets for feedlot calves. J. Anim. Sci., 65: 267-277.

تأثير إضافة الثيامين أو النياسين إلى علائق تسمين العجول على أدائها الإنتاجى

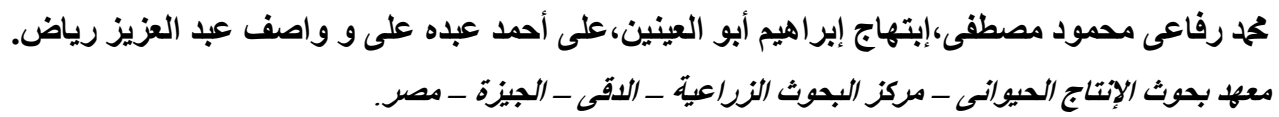

تهدف هذه الدراسة إلى تقييم تأثير إضافة كل من الثيامين والنياسين إلى علائق عجول التسمين الفريزيان على أدائها الإنتاجى وقد

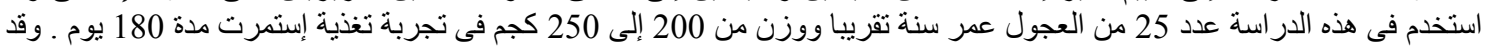

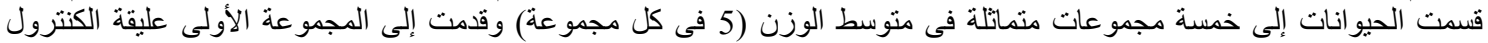

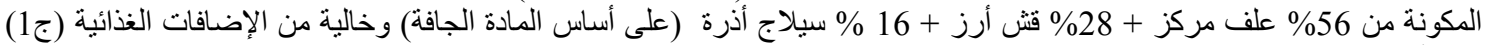

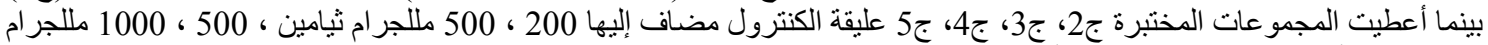

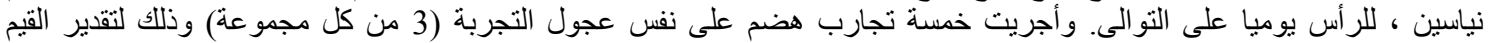

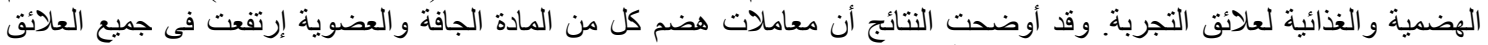

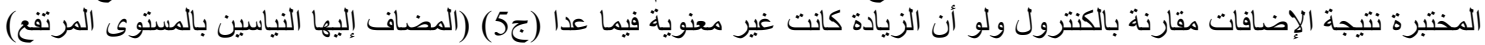

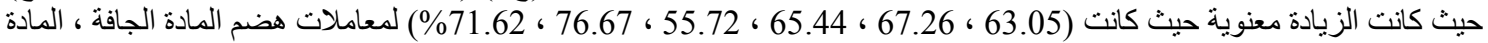

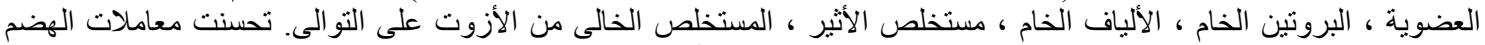

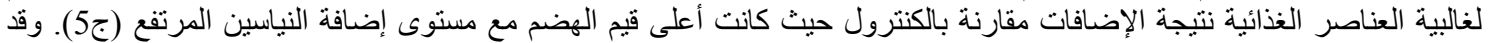

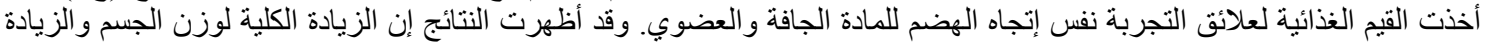

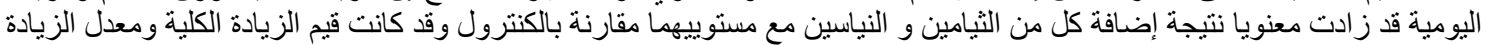

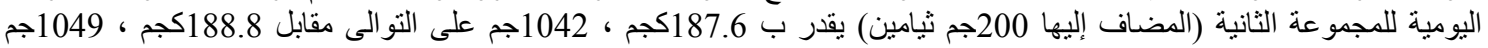

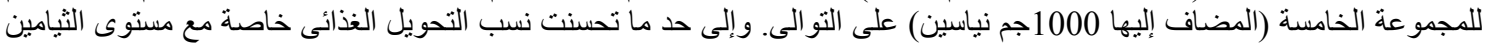

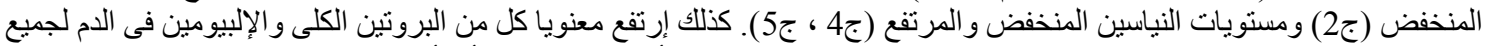

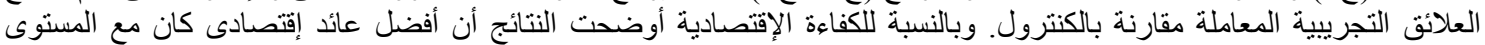

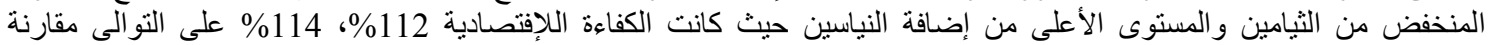

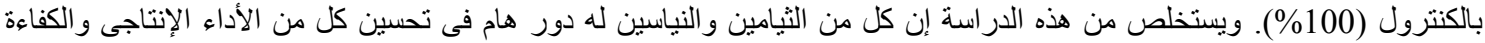
الغذائية وكذللك الكفاءة الإقتصادية عند إضافتها إلى علائق عجول التسمين من الثين خاصة في مرحلة التسمين النهائية. 